\title{
Faktor-Faktor Yang Mempengaruhi Loyalitas Anggota Dojang di Yogyakarta
}

\author{
Petra Surya Mega Wijaya ${ }^{1}$, Maklon Haiti ${ }^{2}$ \\ STIE IEU, J1. Hayam Wuruk 20 Yogyakarta, 55211, Indonesia \\ petra.surya@gmail.com
}

\begin{abstract}
The development of dojang in Yogyakarta shows a pleasant increase because of the increasing number of taekwondo matches on a regional, national and even international scale followed by a large number of dojangs in Yogyakarta. This makes the members of the dojang to compete with each other and even move from one dojang to another because they see that the other dojang is superior to the dojang he is currently attending.

This study aims to examine a number of variables that affect the loyalty of dojang members, including (1) brand image, (2) brand then, (3) satisfaction, (4) servqual, and (5) brand credibility. To answer the research objectives, 100 questionnaires were distributed randomly to a number of large dojang in Yogyakarta. The analytical tool used is multiple linear regression.

The results showed that there were 2 variables that significantly or strongly influenced the loyalty of dojang members, namely (1) brand image, and (2) servqual. While there are 3 variables that do not significantly affect the loyalty of dojang members, namely (1) brand trust, satisfaction, and (3) brand credibility.
\end{abstract}

Keywords: brand loyalty, brand image, brand trust, satisfaction, servqual, brand credibility

\section{PENDAHULUAN}

Perkembangan cabang olah raga beladiri di Indonesia pada umumnya dan Yogyakarta pada khususnya mengalami kemajuan yang cukup baik. Hal ini ditandai dengan berdirinya berbagai perkumpulan bela diri mulai dari tingkat sekolah, perguruan tinggi hingga umum yang dapat diikuti oleh semua kalangan masyarakat.

Salah satu perguruan beladiri yang cukup menarik di Yogyakarta saat ini adalah cabang olah raga taekwondo. Perguruan taekwondo ini pada umumnya disebut dengan dojang. Berbagai dojang berdiri di Yogyakarta dengan memberikan keunikannya masing-masing, diantaranya adalah lokasi, kualitas pelatih (sabuem), fasilitas yang beragam, hingga kesempatan untuk mengikuti berbagai kejuaraan di tingkat daerah, nasional maupun internasional, selain itu juga memberikan kesempatan untuk 


\section{Petra Surya Mega Wijaya, Maklon Haiti}

mendapatkan pekerjaan. Setiap orang saat ini dapat dengan mudahnya memilih dojang mana yang menurutnya lebih baik untuk diikuti sesuai keinginannya.

Permasalahan pokok dari kondisi ini adalah menumbuhkan loyalitas anggota dojang supaya tidak berpindah ke dojang lainnya. Brand loyalty yaitu sebagai menjaga lebih baik untuk produk atau layanan tertentu (Mao, 2010). Loyalitas anggota menjadi pokok pembahasan dalam penelitian ini dengan tujuan menguji sejumlah variabel yang mempengaruhi loyalitas anggota dojang sehingga diharapkan melalui variabel tersebut, para pengelola dojang dapat menentukan kebijakan yang efektif sehingga anggota dojangnya tidak pindah ke dojang lainnya bahkan sedapat mungkin menarik orang lain menjadi anggota dojang yang diikutinya. Variabel yang diduga dapat membentuk loyalitas anggota dojang diantaranya adalah kualitas layanan (service quality), kepercayaan merek (brand trust), citra merek (brand image), kredibilitas (brand credibility), dan kepuasan (satisfaction) (Hashmi et al., 2014 dan Nawaz \& Usman, 2011).

\section{LANDASAN TEORI DAN PENGEMBANGAN HIPOTESIS}

\section{Brand Loyalty}

Brand loyalty yaitu sebagai menjaga lebih baik untuk produk atau layanan tertentu (Mao, 2010). Disisi lainnya, Nawaz dan Usman (2011) menyebutkan brand loyalty adalah respons perilaku dari pembelian yang ditunjukkan dari waktu ke waktu sehubungan dengan pengambilan keputusan untuk satu atau lebih merek dari sejumlah merek dan merupakan bagian dari proses psikologis konsumen tersebut.

Loyalitas adalah perilaku seseorang terhadap produk yang dikonsumsinya. Sejumlah peneliti menyatakan bahwa perilaku konsumen bisa memberikan dampak yang besar pada perkembangan suatu perusahaan supaya semakin mendapatkan kepercayaan dari konsumen (Alhaija, et al., 2018; Mao, 2010).

Berlandaskan hal di atas maka diharapkan perusahaan dapat menggunakan strategi yang diyakini bisa membentuk loyalitas konsumen. Dari loyalitas konsumen terhadap produk yang ditawarkan inilah, maka diharapkan perusahaan mendapatkan pemasukkan rutin sehingga tercapailah target keuntungan yang sudah dicanangkan oleh perusahaan.

\section{Satisfaction}

Kepuasan diyakini merupakan bagian yang krusial dari pembentukan loyalitas konsumen (Ha, Janda, Park, 2009; Nawaz \& Usman, 2011). Loyalitas pelanggan merupakan salah satu cara untuk menunjukan kepuasannya pada suatu produk atau layanan yang diterima. Kepuasan juga sebagai faktor yang dominan terhadap keinginan pembelian kembali suatu merek.

Kepuasan diartikan sebagai fungsi perbedaan antara harapan konsumen sebelum melakukan pembelian dan ekspresinya setelah pembelian tersebut (Leninkumar, 2019; 
Tjiptono, 2007). Ekspresi konsumen sesudah pembelian dapat positif karena produk yang dibelinya melampaui harapannya, tetapi jika kinerja produk yang dibelinya di bawah harapannya, maka muncul tanggapan negative. Kepuasan muncul jika terbangun sikap yang positif, namun sikap negative yang muncul maka menyebabkan ketidakpuasan pada produk yang dikonsumsinya.

Perusahaan berusaha meposisikan kepuasan konsumennya sebagai bagian penting dalam menawarkan produk yang dijualnya, karena dengan adanya kepuasan konsumen maka diharapkan konsumen kembali mengbeli produk perusahaan (Leninkumar, 2019; Nasution, 2005). Produk yang sejalan dengan harapan konsumen dapat menaikkan penjualan produk perusahaan baik jangka pendek, menengah sampai akhirnya jangka panjang.

Berkaitan dengan usaha perusahaan meningkatkan kepuasan konsumen hingga bisa berdampak terhadap pembelian ulang produk, maka hipotesis yang dibangun adalah sebagai berikut.

Hipotesis 1 : satisfaction berpengaruh secara signifikan dan positif terhadap brand loyalty

\section{Service Quality}

Kualitas layanan menarik banyak perhatian dari profesional dan para peneliti karena dapat berakibat terhadap biaya, kepuasan pelanggan, retensi, mulut ke mulut positif, loyalitas pelanggan, kinerja bisnis dan profitabilitas (Leninkumar, 2019). Sejumlah manfaat dari kualitas layanan telah diidentifikasi oleh para peneliti yang menekankan pentingnya kualitas layanan dan pengembangannya di organisasi manapun.

Kualitas jasa dapat diartikan sebagai keseluruhan kesan konsumen secara inferioritas/superioritas relatif terhadap organisasi dan layanannya (Parasuraman, Zeithaml, \& Berry, 1985; Tjiptono, 2007; Fen \& Lian, 2015). Kualitas jasa menjadi hal penting oleh perusahaan, yang ditandai dengan usaha pada pelibatan seluruh sumber daya yang dimiliki perusahaan.

Bagi perusahaan yang bergerak di bidang jasa, kualitas layanan ini menjadi perhatian tersendiri untuk dapat menghasilkan loyalitas konsumennya. Perusahaan berusaha sedapat mungkin memenuhi semua harapan konsumen melalui sejumlah layanan jasa yang ada di perusahaan. Menurut Lopiyoadi dan Hamdani (2006:182) kualitas layanan dapat ditinjau dalam 5 dimensi, yaitu (1) tangibles, (2) reliability, (3) responsiveness, (4) assurance, dan (5) emphaty. Persepsi konsumen memegang peranan sangat penting dalam menilai apakah kualitas layanan dapat dinilai tinggi atau rendah. Semakin tinggi kenyataan yang didapatkan oleh konsumen maka semakin tinggi persepsi kualitas layanannya (Mosahab, Mahamad, \& Ramayah, 2010).

Kualitas layanan diyakini memiliki pengaruh yang sangat kuat pada loyalitas konsumen (Nawaz \& Usman, 2011; Hashmi et.al., 2014). Berdasarkan hal tersebut, maka hipotesis yang diajukan adalah sebagai berikut: 
Hipotesis 2 : service quality berpengaruh secara signifikan dan positif terhadap brand loyalty

\section{Brand Credibility}

Brand credibility dapat diartikan sebagai sebuah ekspresi multi dimensi yang menggambarkan integritas sebuah merek dari sudut pandang seorang konsumen (Hashmi et. al., 2014). Dari definisi tersebut ditegaskan adanya multi dimensi yang ada dalam diri seseorang dapat menilai sebuah merek, baik merek itu dia gunakan atau tidak digunakan. Seseorang pada dasarnya dapat memberikan penilaian atas sebuah merek berdasarkan pemahaman pribadinya maupun dari informasi orang lain. Multi dimensi yang dimaksudkan adalah keandalan, keahlian dan tampilan yang menyenangkan. Ambil contoh merek mobil Ferrari. Seseorang tidak harus memiliki dulu mobil Ferrari untuk bisa menilai mobil tersebut. Seorang konsumen dapat menilai seberapa tinggi tingkat kehandalan mobil tersebut, seberapa tinggi keahlian para staf di pabrik mobil Ferrari untuk dapat diterima kerja, dan dengan mudahnya melihat gambar mobil Ferrari di internet untuk menilai desainnya.

Hashmi et al., (2014), dan Erdem dan Swait (2004) menjelaskan ada pengaruh yang kuat dan positif dari brand credibility terhadap terbentuknya brand loyalty. Sejumlah upaya dilakukan perusahaan untuk dapat meningkatkan brand credibility produk yang dijualnya supaya dapat diterima dengan baik oleh konsumen. Melalui kekuatan brand credibility, perusahaan mengharapkan konsumennya akan terus membeli produk yang dikeluarkan oleh perusahaan, walaupun produk itu adalah produk baru.

Hipotesis 3 : brand credibility berpengaruh secara signifikan dan positif terhadap brand loyalty

\section{Brand Image}

Kotler \& Keller (2012) menyebutkan bahwa brand image merupakan persepsi tentang merek yang tersimpan dalam ingatan konsumen. (Kotler \& Keller, 2012; Yu, Shean, \& Tan, 2013). Brand image diyakini sebagai sebuah ciri dasar dan dapat dikaitkan dengan teori brand identity (Thaker, 2006). Hashmi et al. (2009) juga menambahkan bahwa seorang konsumen memiliki keterikatan emosional tersendiri pada suatu merek tertentu yang pernah digunakannya jika merek tersebut dapat memenuhi harapannya dan tidak akan memiliki merek yang tidak dapat memenuhi harapannya.

Sejumlah penelitian terhadap brand image terakhir ini bermunculan untuk meneliti factor-faktor yang dapat membentuk brand equity (Zhang, 2015). Penelitian ini juga berdasarkan dengan upaya yang dilakukan oleh perusahaan untuk lebih mengenal perilaku konsumennya supaya dapat selalu memenuhi kebutuhannya, sekaligus berupaya menanamkan dibenak konsumen tentang merek perusahaan supaya semakin kuat terbentuk loyalitas produk perusahaan. Semakin tinggi brand image perusahaan maka semakin tinggi pula loyalitas konsumen pada produk perusahaan. 
Hipotesis 4 : brand image berpengaruh secara signifikan dan positif terhadap brand loyalty

\section{Brand Trust}

Brand trust dapat diartikan sebagai keadaan perasaan aman saat berinteraksi dengan merek berdasarkan persepsi bahwa merek akan tetap dapat diandalkan dan bertanggung jawab untuk memuaskan pelanggan (Hashmi et al., 2014; Shin et al., 2019). Persepsi yang terbangun di benak konsumen setelah menggunakan suatu merek tertentu dan dibandingkan dengan merek lainnya. Merek yang sudah banyak dikenal oleh konsumen akan mendapatkan keuntungan yang lebih besar daripada merek yang belum begitu dikenal oleh konsumen, karena hanya sebagian kecil saja konsumen ingin mencoba merek yang baru atau belum dikenal.

Hashmi et al., (2014) menyebutkan bahwa trust adalah sebuah proses perhitungan kemampuan sebuah merek tertentu untuk mempertemukan perkiraan hitungan biaya dibandingkan dengan manfaat yang diperoleh oleh konsumen. Kepercayaan perlu dibangun oleh perusahaan pada semua produk yang dihasilkannya supaya konsumen yang menggunakan produk tersebut tidak merasa kecewa atau merasa ditipu. Kepercayaan juga menjadi kunci bagi konsumen untuk mendesak perusahaan supaya memberikan produk yang dapat dipercaya sesuai harapan konsumen.

Semakin tinggi tingkat kepercayaan konsumen terhadap suatu merek maka diharapkan semakin tinggi pula keinginan konsumen untuk melakukan pembelian kembali produk perusahaan, namun jika kepercayaan ini semakin rendah, maka akan berdampak pada semakin rendahnya keinginan konsumen untuk membeli kembali produk perusahaan dimasa mendatang.

Hipotesis 5 : brand trust berpengaruh secara signifikan dan positif terhadap brand loyalty

\section{METODE PENELITIAN}

Berdasarkan pada pemaparan teori dan pengembangan hipotesis yang telah dibahas sebelumnya, maka secara lebih ringkas dapat digambar model penelitiannya seperti dalam Gambar 1. 


\section{Gambar 1. Model Penelitian}

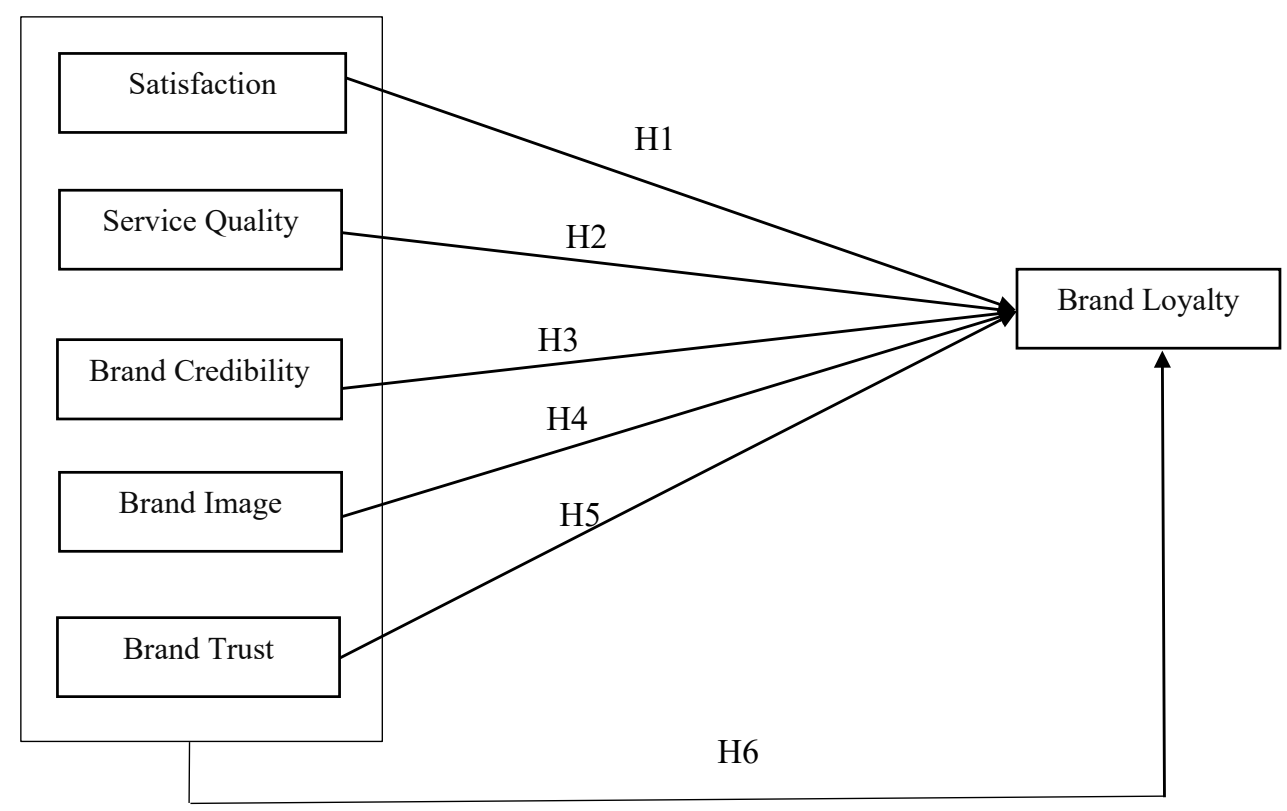

Sumber : Nawas \& Usman (2011), \& Hashmi et al., (2014)

\section{Populasi dan Penentuan Sampel}

Obyek penelitian penelitian ini adalah dojang (pusat pelatihan Tae Kwon Do) yang berada di Yogyakarta. Pemilihan dojang lebih disebabkan karena banyaknya persaingan antar dojang, baik yang dilaksanakan di sekolah maupun dikelola swasta. Pra penelitian menemukan bahwa loyalitas anggota dojang tidak bisa dikatakan tinggi karena terjadi perpindahan antar anggota dojang karena adanya penawaran dari dojang lain yang lebih berprestasi dan lebih banyak anggotanya.

Populasi adalah sekelompok individu dari spesies yang sama yang hidup dan kawin silang di dalam daerah tertentu (Cooper \& Schindler, 2013; Tarsi \& Tuff, 2012). Adapun populasi penelitian ini adalah seluruh anggota dojang besar di Yogyakarta. Pemilihan dojang yang dianggap besar karena pada saat pra penelitian terlihat adanya sejumlah perpindahan anggota dojang ke dojang lainnya yang sedang naik daun karena memiliki prestasi cukup bagus, baik ditingkat daerah, nasional bahkan internasional.

Sampel didefinisikan sebagai memperoleh informasi dari kelompok yang lebih besar atau alam semesta (Cooper \& Schindler, 2013). Teknik sampling yang digunakan adalah random sampling yaitu semua anggota populasi memiliki kesempatan yang sama sebagai responden penelitian. Jumlah responden yang digunakan dalam penelitian ini adalah 100 orang dengan tingkat response rate sebesar $100 \%$. 


\section{Skala Pengukuran}

Skala pengukuran yang digunakan adalah skala likert dengan 5 (lima) pilihan jawaban yaitu mulai dari sangat tidak setuju (diberi angka 1) hingga sangat setuju (diberi angka 5).

\section{Uji Kuesioner}

Pengujian kuesioner digunakan untuk mengukur semua indicator penelitian supaya dapat digunakan untuk menguji hiotesis yang sudah dibangun. Pengujian kuesioner menggunakan 2 (dua) langkah yaitu uji validitas dan uji reliabilitas.

\section{Uji Validitas}

Uji validitas adalah sejauh mana ukuran tampaknya terkait dengan konstruksi tertentu (Marzuki, 2000:298; Taherdoost, 2016). Sebuah indicator dapat dikatakan valid jika memiliki nilai corrected item-Total correlation sama dengan atau lebih besar dari nilai $\mathrm{r}$ tabel. Jika terdapat indicator dengan nilai corrected item-Total correlation kurang dari $r$ tabel maka dinyatakan tidak valid (Sugiyono, 2017). Penelitian ini menggunakan 100 responden, maka $\mathrm{N}=100, \mathrm{df}=100-2=98$, maka $\mathrm{r}$ tabel one tail dengan tingkat signifikansi $5 \%$ nilainya sebesar 0.1654 . Berdasarkan nilai 0.1654 sebagai batas paling bawah nilai indikator corrected item-Total correlation dikatakan bahwa indicator tersebut memenuhi uji validitas.

\section{Uji Reliabilitas}

Reliabilitas yaitu sejauh mana pengukuran suatu fenomena memberikan hasil yang stabil dan konsisten (Sugiyono, 2012:122; Taherdoost, 2016). Pengujian reliabilitas digunakan karena data yang digunakan adalah data primer sehingga variasi pendapat responden bisa sangat beragam. Melalui uji reliabilitas inilah maka keberagaman jawaban responden bisa diukur apakah cenderung konsisten dan stabil dari waktu ke waktu.

Kuesioner yang baik jika memenuhi kriteria reliabilitas atau konsisten dari waktu ke waktu. Pengujian reliabilitas menggunakan koefisien Cronbach's alpha, dengan ukuran minimal 0.6 (Sekaran, 2002, Hair et al., 2009). Sebuah variable jika memiliki nilai Cronbach's alpha sedikitnya 0.6 maka dapat dikatakan reliabel, namun jika nilai Cronbach's alpha di bawah 0.6 maka disimpulkan tidak reliabel.

\section{Uji Hipotesis}

\section{Regresi Linier Berganda}

Alat analisis untuk uji hipotesis menggunakan regresi linier berganda karena jumlah variable independent yang lebih dari 2 (dua) atau lebih tepatnya 5 (lima) variable independen yang digunakan dalam penelitian ini (Ghozali, 2005:82). Adapun rumus persamaan regresinya adalah sebagai berikut: 
$\mathrm{Y}=\mathrm{a}+\mathrm{b}_{1} \mathrm{X}_{1}+\mathrm{b}_{2} \mathrm{X}_{2}+\mathrm{b}_{3} \mathrm{X}_{3}+\mathrm{b}_{4} \mathrm{X}_{4}+\mathrm{b}_{5} \mathrm{X}_{5}+\mathrm{e}$

Dimana :

$\mathrm{Y} \quad=$ Brand loyalty (variable dependen)

$\mathrm{a} \quad=$ Konstanta

$\mathrm{b}_{1,2,3,4,5}=$ Koefisien regresi

$\mathrm{X}_{1} \quad=$ Brand Image (variabel independen)

$\mathrm{X}_{2} \quad=$ Brand Trust (variabel independen)

$\mathrm{X}_{3} \quad=$ Satisfaction (variabel independen)

$\mathrm{X}_{4} \quad=$ Service Quality (variabel independen)

$\mathrm{X}_{5} \quad=$ Brand Credibility (variabel independen)

$\mathrm{e} \quad=$ error term

\section{HASIL DAN PEMBAHASAN}

\section{Hasil Uji Validitas}

Adapun hasil pengolahan data untuk menguji validitasnya, dapat dilihat pada Tabel 1 hingga Tabel 6.

Tabel 1. Hasil Uji Validitas Brand Image

\begin{tabular}{ccccc}
\hline \multicolumn{5}{c}{ Item-Total Statistics } \\
\hline & $\begin{array}{c}\text { Scale Mean if } \\
\text { Item Deleted }\end{array}$ & $\begin{array}{c}\text { Scale Variance if } \\
\text { Item Deleted }\end{array}$ & $\begin{array}{c}\text { Corrected Item- } \\
\text { Total Correlation }\end{array}$ & $\begin{array}{c}\text { Cronbach's Alpha } \\
\text { if Item Deleted }\end{array}$ \\
\hline BI1 & 12.63 & 3.872 & .445 & .711 \\
BI2 & 13.40 & 2.768 & .501 & .698 \\
BI3 & 12.92 & 3.064 & .626 & .605 \\
BI4 & 12.80 & 3.253 & .550 & .650 \\
\hline
\end{tabular}

Tabel 2. Hasil Uji Validitas Brand Trust

\begin{tabular}{ccccc}
\hline \multicolumn{5}{c}{ Item-Total Statistics } \\
\hline & $\begin{array}{c}\text { Scale Mean if } \\
\text { Item Deleted }\end{array}$ & $\begin{array}{c}\text { Scale Variance if } \\
\text { Item Deleted }\end{array}$ & $\begin{array}{c}\text { Corrected Item- } \\
\text { Total Correlation }\end{array}$ & $\begin{array}{c}\text { Cronbach's Alpha } \\
\text { if Item Deleted }\end{array}$ \\
\hline BT1 & 14.18 & 1.846 & .476 & .773 \\
BT2 & 13.89 & 2.079 & .703 & .604 \\
BT3 & 13.81 & 2.782 & .500 & .731 \\
BT4 & 13.95 & 2.109 & .617 & .647 \\
\hline
\end{tabular}


Tabel 3. Hasil Uji Validitas Satisfaction

\begin{tabular}{lrrrr}
\hline \multicolumn{5}{c}{ Item-Total Statistics } \\
\hline & $\begin{array}{c}\text { Scale Mean if } \\
\text { Item Deleted }\end{array}$ & $\begin{array}{c}\text { Scale Variance if } \\
\text { Item Deleted }\end{array}$ & $\begin{array}{c}\text { Corrected Item- } \\
\text { Total Correlation }\end{array}$ & $\begin{array}{c}\text { Cronbach's Alpha } \\
\text { if Item Deleted }\end{array}$ \\
\hline S1 & 12.49 & 2.818 & .611 & .697 \\
S2 & 12.66 & 3.095 & .588 & .705 \\
S3 & 12.36 & 3.324 & .620 & .690 \\
S4 & 12.38 & 3.915 & .495 & .754 \\
\hline
\end{tabular}

Tabel 4. Hasil Uji Validitas Service Quality

\begin{tabular}{lrrrr}
\hline \multicolumn{5}{c}{ Item-Total Statistics } \\
\hline & $\begin{array}{c}\text { Scale Mean if } \\
\text { Item Deleted }\end{array}$ & $\begin{array}{c}\text { Scale Variance if } \\
\text { Item Deleted }\end{array}$ & $\begin{array}{c}\text { Corrected Item- } \\
\text { Total Correlation }\end{array}$ & $\begin{array}{c}\text { Cronbach's Alpha } \\
\text { if Item Deleted }\end{array}$ \\
\hline SV1 & 12.92 & 2.600 & .426 & .618 \\
SV2 & 13.19 & 2.357 & .487 & .577 \\
SV3 & 13.17 & 2.304 & .472 & .589 \\
SV4 & 12.92 & 2.781 & .425 & .622 \\
\hline
\end{tabular}

Tabel 5. Hasil Uji Validitas Brand Credibility

\begin{tabular}{lrrrr}
\hline \multicolumn{5}{c}{ Item-Total Statistics } \\
\hline & $\begin{array}{c}\text { Scale Mean if } \\
\text { Item Deleted }\end{array}$ & $\begin{array}{c}\text { Scale Variance if } \\
\text { Item Deleted }\end{array}$ & $\begin{array}{c}\text { Corrected Item- } \\
\text { Total Correlation }\end{array}$ & $\begin{array}{c}\text { Cronbach's Alpha } \\
\text { if Item Deleted }\end{array}$ \\
\hline $\mathrm{BC} 1$ & 13.75 & 2.109 & .729 & .687 \\
$\mathrm{BC} 2$ & 13.75 & 2.149 & .670 & .717 \\
$\mathrm{BC} 3$ & 13.84 & 2.600 & .398 & .845 \\
$\mathrm{BC} 4$ & 13.65 & 2.169 & .664 & .720 \\
\hline
\end{tabular}

Tabel 6. Hasil Uji Validitas Brand Loyalty

\begin{tabular}{lrrrr}
\hline \multicolumn{5}{c}{ Item-Total Statistics } \\
\hline & $\begin{array}{c}\text { Scale Mean if } \\
\text { Item Deleted }\end{array}$ & $\begin{array}{c}\text { Scale Variance if } \\
\text { Item Deleted }\end{array}$ & $\begin{array}{c}\text { Corrected Item- } \\
\text { Total Correlation }\end{array}$ & $\begin{array}{c}\text { Cronbach's Alpha } \\
\text { if Item Deleted }\end{array}$ \\
\hline BL1 & 12.98 & 2.646 & .215 & .592 \\
BL2 & 12.98 & 2.646 & .413 & .409 \\
BL3 & 12.84 & 2.802 & .422 & .415 \\
BL4 & 13.22 & 2.598 & .324 & .479 \\
\hline
\end{tabular}


Berdasarkan Tabel 1 hingga Tabel 6 didapatkan hasil olah data pengujian validitas. Pada kolom corrected item-Total correlation angka yang paling kecil adalah 0.292 atau di atas 0.1654. Dari hasil ini maka dapat disimpulkan bahwa semua indicator yang digunakan dalam penelitian dapat dikatakan valid.

\section{Hasil Uji Reliabilitas}

Pengujian selanjutnya setelah uji validitas adalah menguji reliabilitas dari semua variable penelitian. Hasil olah uji reliabilitas penelitian dapat dilihat pada Tabel 2.

\section{Tabel 7. Hasil Uji Reliabilittas}

\begin{tabular}{lccc}
\hline \multicolumn{1}{c}{ Variabel } & $\begin{array}{c}\text { Nilai Cronbach's } \\
\text { Alpha }\end{array}$ & $\begin{array}{c}\text { Standar Minimal } \\
\text { Cronbach's Alpha }\end{array}$ & Keterangan \\
\hline Brand Image & 0.728 & 0.6 & Reliabel \\
Brand Trust & 0.748 & 0.6 & Reliabel \\
Satisfaction & 0.769 & 0.6 & Reliabel \\
Service Quality & 0.669 & 0.6 & Reliabel \\
Brand Credibility & 0.798 & 0.6 & Reliabel \\
Brand Loyalty & 0.645 & 0.6 & Reliabel \\
\hline
\end{tabular}

Olah data pengujian reliabilitas yang disajikan pada Tabel 7 menunjukkan angka Cronbach's alpha semua variable di atas 0.6. Berdasarkan pada hasil tersebut maka dapat dikatakan bahwa semua variable penelitian yang diuji memenuhi kriteria uji reliabilitas atau sudah reliabel.

\section{Analisis Regresi Berganda}

Langkah selanjutnya setelah uji validitas dan uji reliabilitas lolos, maka dilakukan pengujian hipotesis atas data-data yang sudah masuk. Adapun hasil olah data pengujian hipotesis terlihat pada Tabel 3.

Tabel 7. Hasil Uji Regresi Berganda

\begin{tabular}{|c|c|c|c|c|c|c|}
\hline \multirow{2}{*}{\multicolumn{2}{|c|}{ Model B }} & \multicolumn{2}{|c|}{ Unstandardized Coefficients } & \multirow{3}{*}{$\begin{array}{c}\text { Standardized } \\
\text { Coefficients }\end{array}$} & \multirow{2}{*}{$\mathbf{t}$} & \multirow{2}{*}{ Sig. } \\
\hline & & Std. Error & Beta & & & \\
\hline \multirow[t]{6}{*}{1} & (Constant) & 1.440 & .486 & & 2.963 & .004 \\
\hline & BI & .397 & .107 & .449 & 3.708 & .000 \\
\hline & BT & .042 & .139 & .039 & .300 & .765 \\
\hline & $\mathrm{S}$ & .034 & .102 & .040 & .339 & .735 \\
\hline & SV & .286 & .107 & .283 & 2.686 & .009 \\
\hline & $\mathrm{BC}$ & .060 & .124 & .057 & .483 & .630 \\
\hline
\end{tabular}




\section{Persamaan Regresi}

Berdasarkan Tabel 7. maka dapat dibuat persamaan regresi untuk variabel yang digunakan dalam penelitian ini sebagai berikut :

$$
\mathrm{Y}=1.440+0.397 \mathrm{X} 1+0.042 \mathrm{X} 2+0.034 \mathrm{X} 3+0.286 \mathrm{X} 4+0.060 \mathrm{X} 5
$$

Penjelasan dari persamaan tersebut adalah sebagai berikut :

1. Jika semua variabel independen dianggap tidak ada atau nilainya nol (0), maka loyalitas (Y) anggota dojang adalah sebesar 1.440.

2. Nilai variabel brand image (X1) adalah positif 0.397 , berarti jika brand image naik satu satuan dan semua variabel independen lain diasumsikan tidak ada atau nilainya nol (0), maka loyalitas anggota dojang akan naik sebesar 0.397 .

3. Nilai variabel brand trust (X2) adalah positif 0.042 , berarti jika brand trust naik satu satuan dan semua variabel independen lain diasumsikan tidak ada atau nilainya nol (0), maka loyalitas anggota dojang akan naik sebesar 0.042 .

4. Nilai variabel satisfaction (X3) adalah positif 0.034 , berarti jika satisfaction naik satu satuan dan semua variabel independen lain diasumsikan tidak ada atau nilainya nol (0), maka loyalitas anggota dojang akan naik sebesar 0.034 .

5. Nilai variabel service quality (X4) adalah positif 0.286 , berarti jika service quality naik satu satuan dan semua variabel independen lain diasumsikan tidak ada atau nilainya nol (0), maka loyalitas anggota dojang akan naik sebesar 0.286 .

6. Nilai variabel brand credibility (X5) adalah positif 0.060 , berarti jika brand credibility naik satu satuan dan semua variabel indepent lain diasumsikan tidak ada atau nilainya nol (0), maka loyalitas anggota dojang akan naik sebesar 0.060.

\section{Uji Regresi Parsial (uji t)}

Sebuah variabel dinyatakan punya pengaruh yang signifikan jika punya nilai signifikansi maksimal 0.05. Berdasarkan Tabel 7. pada kolom 'sig' tersaji bahwa ada dua (2) variabel independen yang mempunyai angka di bawah 0.05 atau dapat dikatakan bahwa variabel independen tersebut mempunyai pengaruh yang signifikan terhadap variabel brand loyalty (loyalitas).

Berikut ini adalah variabel independen yang mempunyai pengaruh signifikan terhadap variable brand loyalty yaitu brand image dengan tingkat signifikansi 0.000 dan variabel service quality sebesar 0.009 . Adapun variabel independen yang tidak signifikan mempengaruhi brand loyalty yaitu brand trust sebesar 0.765 , variabel satisfaction sebesar 0.735 dan brand credibility sebesar 0.630 .

\section{Uji Simultan (uji F)}

Pengujian $\mathrm{F}$ digunakan untuk menguji pengaruh semua variable independen secara bersama-sama terhadap variable dependen. Semua variable independen dikatakan berpengaruh signifikan jika memiliki nilai signifikansi maksimal 0.05. Pada Tabel 8 


\section{Petra Surya Mega Wijaya, Maklon Haiti}

tersaji tingkat signifikansinya 0.000 atau di bawah 0.05 . Dapat disimpulkan bahwa secara bersama-sama variable independen berpengaruh signifikan terhadap brand loyalty anggota dojang di Yogyakarta.

Tabel 8. Hasil Penghitungan Uji F

\begin{tabular}{|c|c|c|c|c|c|c|}
\hline \multicolumn{2}{|r|}{ Model } & Sum of Squares & df & Mean Square & $\mathbf{F}$ & Sig. \\
\hline 1 & Regression & 8.623 & 5 & 1.725 & 9.590 & $.000^{\mathrm{a}}$ \\
\hline & Residual & 16.904 & 94 & .180 & & \\
\hline & Total & 25.527 & 99 & & & \\
\hline
\end{tabular}

a. Predictors: (Constant), BC, S, SV, BI, BT

b. Dependent Variable: BL

\section{Koefisien Determinasi}

Koefisien determinasi digunakan untuk menguji seberapa besar pengaruh semua variable independen terhadap variable dependen. Dari hasil pengujian tersebut maka dapat digunakan untuk dilakukan pengujian selanjutnya guna mendapatkan variablevariabel independen yang memiliki pengaruh yang signifikan sehingga akan memperkuat terbentuknya variable dependen. Tabel 9 merupakan tabel yang menunjukkan seberapa besar pengaruh semua variable independen tersebut.

Tabel 9. Hasil Penghitungan Besaran Pengaruh Variabel Independen terhadap Variabel Dependen

\begin{tabular}{|c|c|c|c|c|}
\hline Model & $\mathrm{R}$ & R Square & Adjusted R Square & $\begin{array}{l}\text { Std. Error of the } \\
\text { Estimate }\end{array}$ \\
\hline 1 & $.581^{\mathrm{a}}$ & .338 & .303 & .42407 \\
\hline
\end{tabular}

Pada Tabel 9. tersaji angka adjusted R square sebesar 0.303 atau 30.3\%. Angka tersebut menyatakan bahwa semua variable independen penelitian berpengaruh sebesar $30.3 \%$ pada terbentuknya variable brand loyalty anggota dojang di Yogyakarta. Sisanya yaitu $66.2 \%$ dipengaruhi oleh variable independen lainnya yang belum masuk dalam penelitian ini.

\section{Analisis Antar Variabel}

\section{Pengaruh Satisfaction terhadap Brand Loyalty}

Berdasarkan Tabel 7. terlihat pengaruh satisfaction terhadap brand loyalty sebesar 0.735 atau di atas 0.05 . Dapat disimpulkan variable satisfaction tidak berpengaruh pada pembentukan brand loyalty.

Hipotesis pertama yang berbunyi satisfaction berpengaruh secara signifikan 
dan positif terhadap brand loyalty tidak terbukti. Hasil ini berbeda dengan penelitian Nawas \& Usman (2011) dan Hashmi et al., (2014).

Hasil penelitian ini menyatakan bahwa kepuasan anggota dojang tidak dapat dikaitkan dengan tingkat loyalitasnya terhadap dojang tersebut. Setinggi apapun kepuasan anggota dojang tidak serta merta dikatakan bahwa anggota tersebut tetap bertahan di dojang tersebut. Temuan ini juga tidak dapat disimpulkan bahwa kepuasan anggota dojang tidak perlu diperhatikan, karena kepuasan tetap memiliki pengaruh pada loyalitas namun pengaruhnya lemah. Anggota dojang tidak hanya mencari kepuasan pada dojang yang diikutinya namun ada faktor yang lainnya, sehingga jika faktor ini tidak terpenuhi maka anggota tersebut akan berpindah ke dojang lainnya yang dapat memenuhi kebutuhannya tersebut.

\section{Pengaruh Service Quality terhadap Brand Loyalty}

Hasil olah data menunjukkan angka signifikansi sebesar 0.009 pada variabel service quality terhadap brand loyalty, jadi disimpulkan bahwa service quality merupakan variabel yang membentuk brand loyalty. Hipotesis 3 yaitu service quality berpengaruh secara signifikan dan positif terhadap brand loyalty terbukti. Penelitian ini sama dengan hasil penelitian Nawas \& Usman (2011) dan Hashmi et al., (2014).

Kualitas pelayanan yang diberikan oleh dojang melalui tenaga pelatih (saboem), tenaga administrasi, dan kelengkapan fasilitas yang tersedia di dojang tersebut dapat mempengaruhi loyalitas anggota dojang. Semakin baik pelayanan yang diberikan maka semakin tinggi loyalitas yang diberikan. Kualitas pelayanan merupakan pelayanan yang diberikan secara personal kepada anggota dojang sehingga mereka langsung merasakan kedekatan personal dengan dojang tersebut. Pada saat anggota dojang ada masalah maka pengurus dojang dapat dengan segera menyelesaikan masalah tersebut sehingga muncul kedekatan yang sangat baik antara pengurus dan anggota dojang.

\section{Pengaruh Brand Credibility terhadap Brand Loyalty}

Tabel 7. memperlihatkan angka signifikansi sebesar 0.630 atau di atas 0.05 , hal ini menandakan tidak ada pengaruh antara brand credibility pada brand loyalty. Jadi hipotesis 3 yang menyatakan brand credibility berpengaruh secara signifikan dan positif terhadap brand loyalty tidak terbukti. Hasil ini berkebalikan dengan penelitian yang dilakukan oleh Nawas \& Usman (2011) dan Hashmi et al., (2014).

Kredibilitas atau nama baik dojang yang selama ini kemungkinan dianggap sebagai sesuatu yang penting untuk mempertahankan anggota dojang dan memperbesar nama dojang ternyata menunjukkan bahwa kurang memiliki pengaruh yang kuat untuk meningkatkan loyalitas anggota dojang. Temuan ini tidak menyatakan bahwa kredibilitas atau nama baik tidak penting, namun untuk dunia taekwondo, nama baik memiliki pengaruh yang lemah pada pembentukan loyalitas anggota dojang. Lebih baik jika pengelola dojang tetap mempertahankan kredibilitasnya namun konsentrasi untuk meningkatkan loyalitas anggota dojang lebih diutama pada variabel yang lainnya. 


\section{Pengaruh Brand Image terhadap Brand Loyalty}

Hasil olah data memperlihatkan variabel brand image berpengaruh signifikan pada brand loyalty dengan nilai signifikansi 0.000 . Dari hasil ini maka hipotesis 4 yaitu brand image berpengaruh secara signifikan dan positif terhadap brand loyalty terbukti. Penelitian ini sejalan dengan penelitian Nawas \& Usman (2011) dan Hashmi et al., (2014).

Temuan ini menunjukkan bahwa seorang anggota dojang sangat memperhatikan citra dojang yang diikutinya, semakin tinggi citra atau semakin terkenal dojang yang diikutinya maka akan semakin loyal anggota tersebut. Hal ini dapat diterima karena dojang yang terkenal dapat membuat bangga anggota dojangnya jika bercerita kepada orang lain atau ditanya berlatih taekwondo di dojang mana. Semakin terkenal nama dojang maka orang yang bertanya tersebut tidak perlu bertanya lebih detail mengenai dojang tersebut, bahkan bisa juga yang terjadi orang tersebut dapat bercerita lebih banyak tentang apa yang dia ketahui mengenai dojang tersebut. Temuan ini dapat menjadi pijakan bagi pengurus dojang untuk lebih meningkatkan citra dojangnya kepada pihak luar supaya semakin terkenal.

\section{Pengaruh Brand Trust terhadap Brand Loyalty}

Brand trust memiliki nilai signifikansi sebesar 0.765 atau di atas 0.05 terhadap brand loyalty. Temuan ini menunjukkan bahwa brand trust tidak berpengaruh pada pembentukan brand loyalty. Hipotesis 5 yaitu brand trust berpengaruh secara signifikan dan positif terhadap brand loyalty tidak terbukti. Penelitian ini berkebalikan dengan penelitian Nawas \& Usman (2011) dan Hashmi et al., (2014).

Upaya dojang untuk memberikan rasa percaya/trust kepada anggota dojang adalah sesuatu yang sewajarnya dilakukan karena jika rasa percaya anggota dojang kepada dojang yang diikutinya hilang maka akan berdampak pada loyalitas yang semakin rendah. Berkaitan dengan hasil olah data, menyatakan bahwa kepercayaan anggota dojang tidak memiliki dampak yang kuat pada loyalitas anggota dojang kepada dojang yang diikutinya sekarang ini. Terdapat sesuatu yang lebih penting bagi anggota dojang untuk mendapatkan hal lainnya daripada hanya mendapatkan kepercayaan/trust.

\section{KESIMPULAN}

Hasil olah data statistik memberikan hasil sebagai berikut :

a. Satisfaction tidak berpengaruh atau tidak signifikan namun positif pada brand loyalty.

b. Service quality berpengaruh atau signifikan dan positif pada brand loyalty.

c. Brand credibility tidak berpengaruh atau tidak signifikan namun positif pada brand loyalty.

d. Brand image berpengaruh atau signifikan dan positif pada brand loyalty. 
e. Brand trust tidak berpengaruh atau tidak signifikan namun positif pada brand loyalty.

f. Secara bersama-sama semua variabel independen berpengaruh atau signifikan pada brand loyalty.

\section{DAFTAR PUSTAKA}

Alhaija, A.S.A., Hashim, H., Nerina, R., Jaharuddin, N.S., 2018, Determinants of Customer Loyalty: E Review and Future Directions, Australian Journal of Basic and Applied Sciences, Vol 12(7): 106-111.

Cooper, D.R., \& Schindler, P.S., 2013, Business research methods. $12^{\text {th }}$ Ed, McGrawHill.

Erdem, T., \& Swait, J., 2004, Brand Credibility, Brand Consideration and Choice, Journal Consumers, Vol.31: 191-198.

Fen, Y.S., \& Lian, K.M., 2015, Service Quality and Customer Satisfaction: Antecedents of Customer's Re-Patronage Intentions, Sunway Academic Journal, Vol 4: 59-73.

Ghozali, I., 2005, Aplikasi Analisis Multivariate dengan Program SPSS, Badan Penerbit Universitas Diponegoro, Semarang.

Ha, H.Y., Janda, S., Park, S.K., 2009, Role of Satisfaction in an Integrative Model of Brand Loyalty: Evidence from China and South Korea, International Marketing Review, Vol 26(2): 198-220.

Hair, J.F, Jr., Anderson, R.E., Tatham, R.L., \& Black, W.C., 2009, Multivariate Data Analysis. $7^{\text {th }} \mathrm{Ed}$, Prentice-Hall International, Inc.

Hashmi, F.K.H., Khalid, F., Akram, M.A., Saeed, U., Rizwan, M., 2014, An Empirical Study of Brand Loyalty on Samsung Electronics in Pakistan, Journal of Sociological Research, Vol.5(1): 350-364.

Kotler, P., \& Keller, K.L ., 2012, Marketing Management, Edisi 14, New Jersey, Pearson Education

Leninkumar, V., 2019, Antecedents of Customer Satisfaction, Archives of Business Research, Vol 7(6): 62-76.

Lopiyoadi, R., \& Hamdani, A., 2006, Manajemen Pemasaran Jasa, PT Salemba Empat, Jakarta.

Mao, J., 2010, Customer Brand Loyalty, International Journal of Business and Management, Vol 5(7): 213-217.

Marzuki., 2000, Statistik Terapan Untuk Penelitian Ilmu-Ilmu Sosial, Gadjah Mada University, Yogyakarta 


\section{Petra Surya Mega Wijaya, Maklon Haiti}

Mosahab, R., Mahamad, O., \& Ramayah, T., 2010, Service Quality, Customer Satisfaction and Loyalty: A Test of Mediation, International Business Research, 3(4): 72-80.

Nasution, M., 2005, Total Quality Management, PT Gramedia Pustaka Utama, Jakarta.

Nawaz, N.U.A., \& Usman, A., 2011, What Makes Customers Brand Loyal : A Study on Telecommunication Sector of Pakistan, International Journal of Business and Social Science, Vol.5(14): 213-221.

Parasuraman, A., Zeithaml, V.A., \& Berry, L.L., 1985, “A conceptual model of service quality and its implication", Journal of Marketing, Vol.49: 41-50.

Sekaran, U., 2002, Research Methods For Business: A Skill-Building Approach, $4^{\text {th }} \mathrm{Ed}$, John Wiley \& Sons Inc, Singapore.

Shin, S.K.S., Amenuvor, F.E., Basilisco, R., \& Antwi, K.O., 2019, Brand Trust and Brand Loyalty: A Moderation and Mediation Perspective, Current Journal of Applied Science and Technology, Vol 38(4): 1-17.

Sugiyono., 2012, Metode Penelitian Kuantitatif Kualitatif dan $R \& D$, Alfabeta, Bandung.

Sugiyono., 2017, Metode Penelitian Kuantitatif Kualitatif dan $R \& D$, Alfabeta, Bandung.

Tjiptono, F., 2005, Pemasaran Jasa, Bayu Media, Malang.

Taherdoost, H., 2016, Validity and Reliability of the Research Instrument; How to Test the Validation of a Questionnaire/Survey in a Research, International Journal of Academic Research in Management, Vol 5(3): 28-36.

Tarsi, K., \& Tuff, T., 2012, Introduction to Population Demographics, Nature Education Knowledge, Vol (3(11):1-9.

Thaker, M., 2006, Brand Origin: Conceptualization and Review, Journal of Consumer Marketing, Vol 13(3): 27-42.

Tjiptono, F., 2007, Strategi Pemasaran. Edisi ke dua, Penerbit Andi, Yogyakarta.

Yu, T.T., Shean, Y.L., \& Tan, K.H., 2013, The Impact of Brand Image and Customer Commitment on Loyalty: an Empirical Study of Automobile Sector, Information Management and Business Review, Vol 5(4): 181-193.

Zhang, Y., 2015, The Impact of Brand Image on Consumer Behavior: A Literature Review, Journal of Business and Management, Vol. 3: 58-62. 